Collection: IUFRO 7.01.00 - COST Action FP0903, Kaunas (Lithuania - 2012)

"Biological Reactions of Forest to Climate Change and Air Pollution"

Guest Editors: Elena Paoletti, Andrzej Bytnerowicz, Algirdas Augustaitis

\section{Effects of planted European beech on the understory in Scots pine forests of Lithuania}

\author{
Vitas Marozas ${ }^{(1)}$, Algirdas Augustaitis ${ }^{(1)}$, Kestutis Armolaitis ${ }^{(2)}$, Almantas \\ Kliucius ${ }^{(1)}$, Mantas Pilkauskas ${ }^{(1)}$
}

Understanding how the planting of non-native species impacts native vegetation is of most importance for forest management, as introduced species may alter environmental conditions with respect to soil composition, light intensity, and species composition. Here, we compared the stand structure, understory vegetation and site properties of a natural Scots pine (Pinus sylvestris L.) stand with Norway spruce (Picea abies (L.) Karst.) and European beech (Fagus sylvatica L.) as the second tree layer. We recorded saplings and species and their abundance in the understory vegetation, the thicknesses of organic (O) and humus (A) soil layers, soil $\mathrm{pH}$ and light indexes in nine Scots pine stands with a second tree layer of beech and in nine control pine stands with a second tree layer of spruce. An ordination method was used to analyze all the data together and ANOVA to determine whether there were differences between stands. We found that species diversity in pine stands with planted beech as the second layer was lower than in pine stands with spruce as the second layer. In pine stands with beech as the second tree layer, shrub, herb and moss cover was significantly lower, and the soil humus layer and organic soil layer were thicker and thinner, respectively. Stand parameters such as mean volume and mean annual increment of the second tree layer were significantly higher in pine stands with planted beech as the second tree layer than in pine stand with spruce as the second tree layer. The mean volume and the mean annual increment of the first tree layer dominated by Scots pine did not differ significantly between stands with planted beech and those with natural spruce. Scots pine stands with a beech second layer had negative effects on understory species richness and abundance. This effect was most likely due to the lower light transmittance and poor physical properties of the forest-floor litter in the Scots pine stands with planted beech.

Keywords: Non-native Tree Species, Fagus sylvatica, Litter, Pinus sylvestris, Soil, Species Richness, Vegetation, Vertical Structure

\section{Introduction}

Extensive plantations of non-native, highly-productive tree species having high commercial value of wood have been carried out in several countries. However, to ensure sustainable management, it is necessary to know the effects of planted tree species on ecosys-

tem diversity, structure and function $(\mathrm{Au}-$ gusto et al. 2003, Gilliam 2007).

Understanding the effect of planted trees on understory species is important because these species play an important role in the functioning of forest ecosystems. Tree species in the stand can affect understory vege-

$\square$ (1) Faculty of Forestry and Ecology, Aleksandras Stulginskis University, Studentu 11, Akademija, LT-53361 Kaunas distr. (Lithuania); (2) Institute of Forestry, Lithuanian Research Centre for Agriculture and Forestry (LRCAF), Liepu 1, Girionys, LT-53101 Kaunas distr. (Lithuania)

@ Vitas Marozas (vitas.marozas@asu.lt)

Received: Jul 20, 2012 - Accepted: May 17, 2013

Citation: Marozas V, Augustaitis A, Armolaitis K, Kliucius A, Pilkauskas M, 2014. Effects of planted European beech on the understory in Scots pine forests of Lithuania. iForest 7: 1218 [online 2013-10-07] URL: http://www.sisef.it/iforest/contents/?id=ifor0695-007

Communicated by: Renzo Motta tation by changing the physical and chemical features of the litter and topsoil, as well as the leaf area index, which determines the amount of light reaching the understory (Kirby 1988, Augusto et al. 2003, Jennings et al. 1999, North et al. 2005, Estevan et al. 2007, Barbier et al. 2008). Several studies on the impact of tree species on leaf-litter (Facelli \& Pickett 1991, Ellsworth et al. 2004) and soil properties (Ewald 2000, Neirynck et al. 2000, Aubert et al. 2004, Hagen-Thorn et al. 2004, Marcos et al. 2010) have been conducted. Previous studies have also compared the stand structure of plantations and natural forests (Kint et al. 2006) and the effects of overstory species on understory plant species (Deal 2007, Gracia et al. 2007, Marcos et al. 2007, Riepsas \& Straigyte 2008, Straigyte et al. 2012).

To improve forestry practices and account for forest ecosystem biodiversity, additional studies that compare stand structure and its effects on the understory vegetation of plantations and natural forests are crucial, especially in stands including non-native species. The presence of a second (intermediate) tree layer greatly modifies understory vegetation, especially due to its effects on light regimes and site properties.

European beech (Fagus sylvatica L.) is the most commercially important tree species in central Europe. Beech is a shade-tolerant, highly competitive species that tolerates a wide variety of environmental conditions (Leuschner et al. 2006). However, beech is sensitive to drought, which restricts its distribution mainly to sub-oceanic regions.

Beech is one of the most recent tree species spreading to northern European territories after the last glaciation. Although European beech may still be migrating northwards, it is limited by various climatic factors (Björkman \& Bradshaw 1996). The north-eastern limit of its range is primarily determined by low winter temperatures and late spring frosts (Huntley et al. 1989, Augustaitis et al. 2012). It has been argued that European beech is expanding its range in northeastern Europe (Giesecke et al. 2007, Bolte et al. 2010). Due to climate change, mean annual air temperature at the northeastern bounds of its distribution is expected to increase by a further $2-5{ }^{\circ} \mathrm{C}$ by the end of this century (IPCC 2007). Climate warming is predicted to increase winter precipitation but slightly decrease summer rainfall (IPCC 2007); these changes may favor the expansion of European beech in north-eastern Europe.

Only a few studies have examined European beech tree growth and its effect on understory vegetation outside its natural distribution range. The aim of this study was to test differences of the stand structure, understory vegetation and site properties between natural Scots pine (Pinus sylvestris L.) forest 


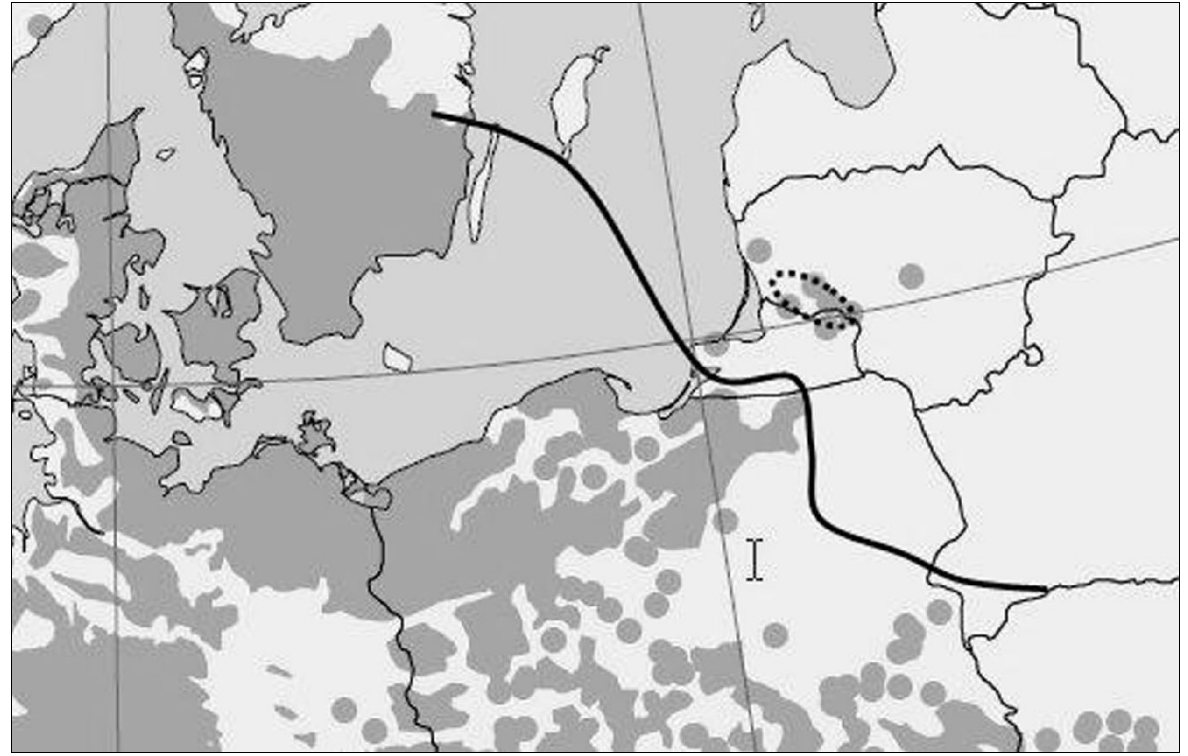

Fig. 1 - European beech range in north-eastern Europe (grey area), its distribution limits (continuous line) and the location of the study sites (dotted line). Adapted from von Wuehlisch (2008).

with a Norway spruce (Picea abies (L.) Karst.) as second tree layer and Scots pine stand with a second tree layer of planted European beech growing outside of its distribution area. We hypothesized that planted beech trees as a second tree layer affect stand structure, species diversity, soil properties, and light conditions of pine stands.

\section{Material and methods}

\section{Study area}

The study area was situated about $150 \mathrm{~km}$ north-east of the limit of the natural distribution of European beech in Poland (Fig. 1). The study plots were located in the western part of Lithuania in the forests of Norkaicia $(55.448 \mathrm{~N} ; 21.519 \mathrm{E})$ and Viesvile (55.078 $\mathrm{N} ; 22.397 \mathrm{E}$ ).

The altitude at the study site was $50-70 \mathrm{~m}$ a.s.1. The average annual temperature was 6.3-6. ${ }^{\circ} \mathrm{C}$, with an average January (coldest month) temperature of $-3.2{ }^{\circ} \mathrm{C}$ and an average July (warmest month) temperature of 16.3 ${ }^{\circ} \mathrm{C}$. Annual precipitation was $750-800 \mathrm{~mm}$. The frost-free period lasts 160-170 days, with permanent snow cover for 75-80 days (Bukantis 1994). The study area was characterized by sandy, acidic, nutrient-poor soils, and pure Scots pine stands were the prevailing forest type.

The study was carried out on 90-125-yearsold Scots pine stands with a second layer dominated by Norway spruce or European beech. European beech was planted during the period 1945-1955. All of the stands were growing on nutrient-poor sandy Arenosols (forest type: Vaccinio-myrtillo Pinetum). The following species prevailed in the un- derstory vegetation: Vaccinium myrtillus, $V$. vitis-idaea, Festuca ovina, Luzula pilosa and Melampyrum pratense in the dwarf shrub and herb layer, and Dicranum polysetum, D. scoparium, Hylocomium splendens and Pleurozium schreberi in the moss layer.

\section{Sampling}

Sampling of stand parameters included recording saplings and species and their abundance in the understory vegetation, and determining the thicknesses of organic $(\mathrm{O})$ and humus (A) soil layers, soil $\mathrm{pH}$ and light indexes in nine Scots pine stands with a second tree layer of beech and in nine control pine stands with a second tree layer of spruce. Control stands were located close to stands with beech.

Sampling was conducted in July and August 2011. A circular sample plot with an area of $500 \mathrm{~m}^{2}(\mathrm{r}=12.62 \mathrm{~m})$ was laid out in a homogenous area located in the center of each stand. The diameters of all trees ( $\mathrm{dbh}>$ $8 \mathrm{~cm}$ ) were measured at a height of $1.3 \mathrm{~m}$. Five to ten trees of medium height for each species were selected and their height measured using the ultrasonic hypsometer Vertex III. Age was determined by counting the number of tree rings in cores from five trees. Tree density, basal area and volume were estimated for each stand. Volume was estimated using local models used in the inventory of Lithuanian forests (Repšys 1994). The number of saplings was recorded in $50 \mathrm{~m}^{2}$ circular sample plots, and species and heights of saplings were noted. Trees of up to $4 \mathrm{~m}$ in height were considered as saplings (Repšys 1994).

Herbaceous and moss species composition and abundance were recorded for each species according to the Braun-Blanquet method (Braun-Blanquet 1983). The overall percentage of cover for each vegetation layer (trees I and II layers, shrub, herb and moss layers) was also estimated. All plant species were classified according to the nomenclature of Jankevičiene (1998). Tree species were assigned to different layers according to their heights (shrub layer, trees up to $4 \mathrm{~m}$; tree II layer, trees whose height differed by more than $25 \%$ from tree I layer). In each plot, the thicknesses of the organic $(\mathrm{O})$ soil and humus (A) soil layers were obtained by averaging the results of a set of five replicate measurements. Composite soil samples of 0$10 \mathrm{~cm}$ mineral soil layers were sampled for $\mathrm{pH}$ measurements, carried out potentiometrically in a $1 \mathrm{M} \mathrm{CaCl}_{2}$ suspension at the Agrochemical Research Laboratory.

Light availability was quantified by digital hemispherical photographs taken in the center of each plot using the equipment and software Hemiview (Delta-T devices Ltd., Cambridge, UK). A self-leveling camera mounted on tripod was positioned $1 \mathrm{~m}$ above the ground. The camera was oriented to magnetic north, and exposure and aperture were set according to the manufacturer's recommendations (Delta-T Devices Ltd., Cambridge, UK). To obtain high-quality, evenly exposed photographs, photos were taken when the sky was overcast. Photographs were analyzed using the Hemiview software. Image classification was performed manually using the threshold algorithm Hemiview according to the recommendations in the user manual. For further data analyses, we used the indirect site factor (ISF), direct site factor (DSF), global site factor (GSF) and leaf area index (LAI) as measures of light intensity (Webb 1999).

\section{Data analyses}

An ordination method was used to analyze all the data from seven plots pooled together. Vegetation data (abundance of each species) fwere considered as the dependent (response) variables. Tree, shrub, herb and moss layer cover, and stand (volume and mean annual increments of I and II stand layers), soil (thickness of $\mathrm{O}$ and A layers, soil $\mathrm{pH}$ ) and light (ISF, DSF, GSF, LAI) parameters were independent (explanatory) variables in the analysis.

Detrended Correspondence Analysis (DCA) was first applied to test the data set for unimodality. Since the length of the gradient was long (more than $3 \mathrm{SD}$ ), a $\mathrm{Ca}$ nonical Correspondence Analysis (CCA) was used to compare all the results globally (Lepš \& Šmilauer 2003). Generalized additive modeling (GAM) was then applied to assess species responses on the CCA axes (Lepš \& Šmilauer 2003). The CANOCO package was used for both ordination ana- 


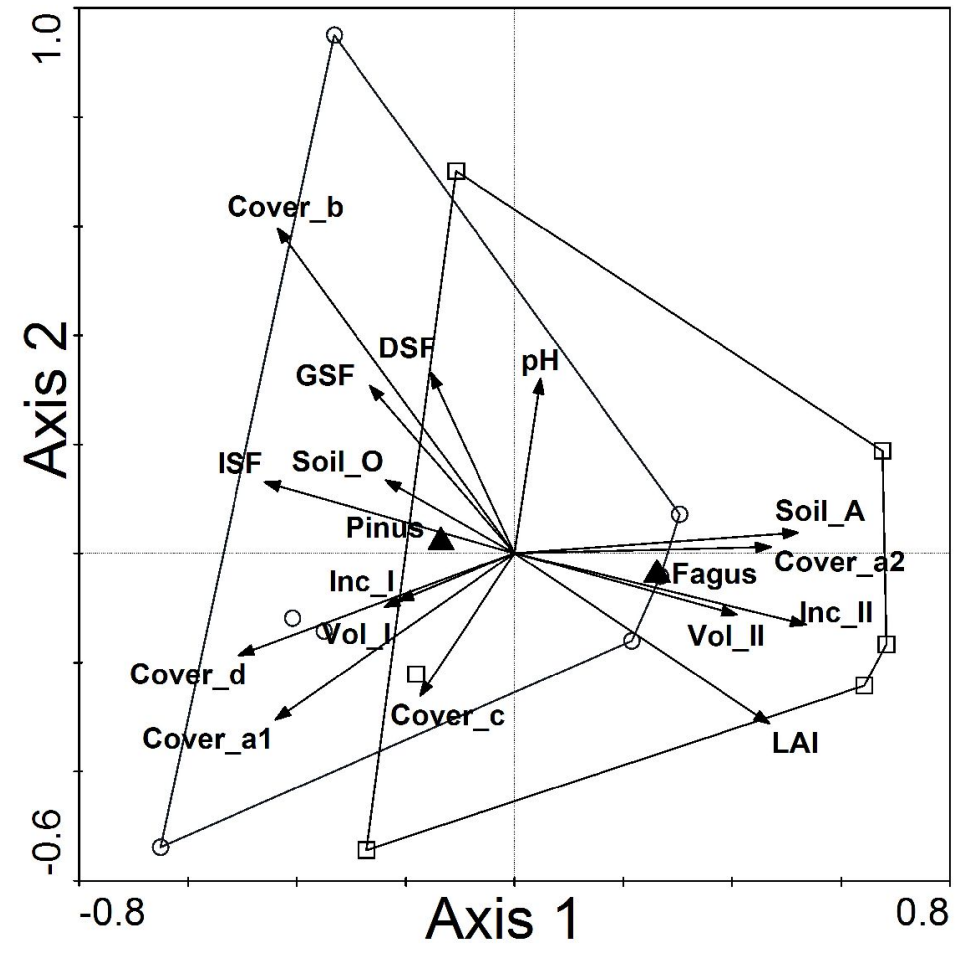

Fig. 2 - Canonical Correspondence Analysis (CCA) of understory vegetation with stand structure indexes and environmental variables for Scots pine stands with beech and spruce as second layers. (Cover_a1): cover of I tree layer;

(Cover_a2): cover of II tree layer; (Cover_b): cover of shrubs; (Cover_c): cover of herbs; (Cover_d): cover of mosses; (DSF): direct site factor; (Fagus): Scots pine stands with beech as second layer; (GSF): global site factor; (ISF): indirect site factor; (Inc_I): mean annual increment of I tree layer; (Inc_II): mean annual increment of tree II tree layer; (LAI): leaf area index; (Pinus): Scots pine stands with beech as second layer; $(\mathrm{pH}): \mathrm{pH}_{\mathrm{CaC} 12}$ of mineral soil at a depth of $0-10$ $\mathrm{cm}$; (Soil_O): soil organic layer O; (Soil_A): soil layer A; (Vol_I): mean volume of I tree layer; (Vol_II): mean volume of I tree layer. lyses and generalized additive modeling (ter Braak \& Šmilauer 1998).

Shannon's (H) and Simpson's (D) diversity indexes were calculated to assess differences in species richness among plots. ANOVA was performed using species richness, stands, soil parameters and light indexes to verify whether there were differences between pine stands with spruce as the second tree layer and pine stands with beech as the second tree layer.

\section{Results}

The joint comparison obtained by CCA differentiated the studied stands (Fig. 2). CCA of vegetation data with stand structure parameters, soil properties and light indexes indicated that pine stands with beech as the second tree layer clustered mostly together and were distinct from pine stands with spruce as the second tree layer along CCA Axis 1.

Compared to Scots pine stands with spru- ce, Scots pine stands with planted beech were associated with thicker humus (A) soil layers and more abundant second tree layers, with higher volume, a mean annual increment of second stand layer and LAI. Pine stands with spruce as the second tree layer were associated with thicker organic $(\mathrm{O})$ soil layers, more abundant moss, herb and shrub coverage, higher volume, a mean annual increment of first stand layer, ISF, DSF and GSF (Tab. 1).

Tab. 1 - Correlation of explanatory variables with the axes of canonical correspondence analysis (CCA) and with plots of Scots pine stands with beech and spruce as second layers. (AX1): CCA axis1; (AX2): CCA axis2; (AX3): CCA axis3; (AX4): CCA axis4; (Cover_a1): cover of I tree layer; (Cover_a2): cover of II tree layer; (Cover_b): cover of shrubs; (Cover c): cover of herbs; (Cover_d): cover of mosses; (DSF): direct site factor; (Fagus): Scots pine stands with beech as second layer; (GSF): global site factor; (ISF): indirect site factor; (Inc I): mean annual increment of I tree layer; (Inc_II): mean annual increment of tree II tree layer; (LAI): leaf area index; (Pinus): Scots pine stands with beech as second layer; $(\mathrm{pH})$ : $\mathrm{pH}_{\mathrm{CaCl} 2}$ of mineral soil at a depth of 0-10 cm; (Soil_O): soil organic layer O; (Soil_A): soil layer A; (Vol_I): mean volume of I tree layer; (Vol_II): mean volume of I tree layer.

\begin{tabular}{lcccrrr}
\hline Parameters & AX1 & AX2 & AX3 & AX4 & Fagus & Pinus \\
\hline Cover_a1 & -0.5796 & -0.4021 & 0.471 & 0.1397 & -0.4827 & 0.4827 \\
Cover_a2 & 0.8941 & 0.022 & -0.0707 & 0.0562 & 0.8913 & -0.8913 \\
Cover_b & -0.4748 & 0.6493 & -0.4927 & 0.1532 & -0.5485 & 0.5485 \\
Cover_c & -0.4905 & -0.7377 & 0.2717 & -0.1658 & -0.3884 & 0.3884 \\
Cover_d & -0.8916 & -0.3283 & 0.2918 & -0.1059 & -0.8259 & 0.8259 \\
Soil O & -0.4735 & 0.2675 & 0.5167 & -0.5469 & -0.5348 & 0.5348 \\
Soil A & 0.6745 & 0.0492 & -0.3054 & 0.0753 & 0.6436 & -0.6536 \\
pH & 0.0551 & 0.368 & -0.4784 & -0.0641 & -0.0177 & 0.0177 \\
Vol I & -0.2456 & -0.101 & 0.0092 & -0.0598 & -0.2428 & 0.2428 \\
Vol II & 0.8412 & -0.2328 & -0.1078 & 0.0837 & -0.8832 & 0.8832 \\
Inc I & -0.2706 & -0.1104 & -0.016 & -0.063 & -0.2667 & 0.2667 \\
Inc II & 0.8651 & -0.2121 & -0.0643 & 0.0874 & 0.9042 & -0.9042 \\
ISF & -0.8611 & 0.2447 & 0.2855 & -0.2802 & -0.8926 & 0.8926 \\
DSF & -0.1852 & 0.3981 & 0.0028 & 0.1853 & -0.2569 & 0.2569 \\
GSF & -0.3789 & 0.4386 & 0.0708 & 0.1115 & -0.4545 & 0.4545 \\
LAI & 0.6332 & -0.4222 & -0.3894 & 0.2783 & 0.6913 & -0.6913 \\
\hline
\end{tabular}


Tab. 2 - Characteristics of vegetation and soil properties in Scots pine stands with either beech (Pinus sylvestris - Fagus sylvatica) or spruce (Pinus sylvestris - Picea abies) as second layers. (H): Shannon's diversity index; (D'): Simpson's diversity index; (SD): standard deviation; (Min): minimal value; (Max): maximal value; [p (F-test)]: significance value.

\begin{tabular}{|c|c|c|c|c|c|c|c|c|c|}
\hline \multirow{2}{*}{ Parameters } & \multicolumn{4}{|c|}{ Pinus sylvestris - Fagus sylvatica } & \multicolumn{4}{|c|}{ Pinus sylvestris - Picea abies } & \multirow{2}{*}{ p (F-test) } \\
\hline & Mean & SD & Min & Max & Mean & SD & Min & Max & \\
\hline Species number & 7.28 & 3.147 & 4 & 12 & 17.85 & 1.069 & 16 & 19 & 0.0000 \\
\hline $\mathrm{H}$ & 1.847 & 0.491 & 1.194 & 2.378 & 2.818 & 0.075 & 2.694 & 2.93 & 0.0002 \\
\hline D' & 0.797 & 0.097 & 0.66 & 0.887 & 0.931 & 0.006 & 0.922 & 0.939 & 0.0034 \\
\hline Cover of I tree layer & 53.28 & 9.759 & 40 & 65 & 47.71 & 7.867 & 40 & 60 & 0.0683 \\
\hline Cover of II tree layer & 60 & 5.773 & 50 & 70 & 10 & 7.071 & 5 & 20 & 0.0000 \\
\hline Cover of shrubs, $\%$ & 0.8 & 1.852 & 0.1 & 5 & 7.14 & 5.669 & 5 & 20 & 0.0125 \\
\hline Cover of herbs, $\%$ & 1.47 & 2.41 & 0 & 5 & 30.71 & 10.965 & 10 & 40 & 0.0001 \\
\hline Cover of mosses, $\%$ & 0 & 0 & 0 & 0 & 45.71 & 9.759 & 30 & 60 & 0.0000 \\
\hline Soil org. layer $\mathrm{O}, \mathrm{cm}$ & 4.25 & 1.368 & 2.6 & 6.6 & 8.08 & 1.018 & 6.9 & 9.6 & 0.0000 \\
\hline Soil layer A, cm & 11.35 & 5.461 & 6.5 & 22.6 & 4.98 & 2.16 & 2.6 & 8.3 & 0.0106 \\
\hline $\mathrm{pH}_{\mathrm{CaCl} 2}(\min$. soil: $0-10 \mathrm{~cm})$ & 3.4 & 0.207 & 3.2 & 3.7 & 3.45 & 0.237 & 3.2 & 3.8 & 0.5000 \\
\hline
\end{tabular}

Tab. 3 - Characteristics of stand parameters in Scots pine stands with beech (Pinus sylvestris - Fagus sylvatica) and spruce (Pinus sylvestris - Picea abies) as second layers. (SD): standard deviation; (Min): minimal value; (Max): maximal value; [p (F-test)]: significance value.

\begin{tabular}{|c|c|c|c|c|c|c|c|c|c|}
\hline \multirow{2}{*}{ Parameters } & \multicolumn{4}{|c|}{ Pinus sylvestris - Fagus sylvatica } & \multicolumn{4}{|c|}{ Pinus sylvestris - Picea abies } & \multirow{2}{*}{ p (F-test) } \\
\hline & Mean & SD & Min & Max & Mean & SD & Min & Max & \\
\hline Mean volume of I layer, $\mathrm{m}^{3}$ & 514.7 & 102.69 & 318 & 660 & 559.6 & 63.49 & 526 & 590 & 0.2936 \\
\hline Mean volume of II layer, $\mathrm{m}^{3}$ & 252.4 & 35.51 & 192 & 291 & 72.8 & 13.49 & 53 & 98 & 0.0005 \\
\hline Mean annual increment of I layer, $\mathrm{m}^{3}$ & 4.54 & 1.067 & 3.18 & 6.13 & 5.38 & 0.751 & 4.67 & 5.81 & 0.0869 \\
\hline Mean annual increment of II layer, $\mathrm{m}^{3}$ & 4.01 & 0.721 & 3.15 & 5.2 & 1.45 & 0.269 & 1.28 & 1.76 & 0.0052 \\
\hline
\end{tabular}

Tab. 4 - Characteristics of light indices in Scots pine stands with beech (Pinus sylvestris - Fagus sylvatica) and spruce (Pinus sylvestris Picea abies) as second layers. (SD): standard deviation; (Min): minimal value; (Max): maximal value; [p (F-test)]: significance value.

\begin{tabular}{|c|c|c|c|c|c|c|c|c|c|}
\hline \multirow{2}{*}{ Parameters } & \multicolumn{4}{|c|}{ Pinus sylvestris - Fagus sylvatica } & \multicolumn{4}{|c|}{ Pinus sylvestris - Picea abies } & \multirow{2}{*}{ p (F-test) } \\
\hline & Mean & SD & Min & Max & Mean & SD & Min & Max & \\
\hline Indirect site factor (ISF) & 0.091 & 0.0244 & 0.06 & 0.114 & 0.236 & 0.0226 & 0.19 & 0.256 & 0.0000 \\
\hline Direct site factor (DSF) & 0.089 & 0.0302 & 0.05 & 0.124 & 0.134 & 0.0356 & 0.092 & 0.198 & 0.0260 \\
\hline Global site factor (GSF) & 0.089 & 0.0282 & 0.05 & 0.123 & 2.395 & 0.1953 & 0.121 & 0.197 & 0.0013 \\
\hline Leaf area index (LAI) & 2.977 & 0.3486 & 2.53 & 3.386 & 2.395 & 0.1953 & 2.17 & 2.759 & 0.0035 \\
\hline
\end{tabular}

Results from ANOVA carried out on species number, Shannon's and Simpson's diversity indexes showed significant differences between pine stands with either beech or spruce as second tree layers. Species diversity in pine stands with spruce as the second layer was higher than in pine stands with planted beech as the second tree layer (Tab. 2). Stand structure parameters such as vegetation layer coverage were significantly different (except tree layer I) in the two forest types. Shrub, herb and moss layer cover was significantly lower in pine stands with beech as the second tree layer than in pine stands with spruce as the second tree layer. This was also the case for soil O and A layers. There was no significant difference in $\mathrm{pH}$ values (Tab. 2).

The ANOVAs carried out on stand parameters, including mean volume and mean annual increment of the second tree layer, showed significant differences between pine stands with beech and those with spruce, and the mean volume and mean annual incre-

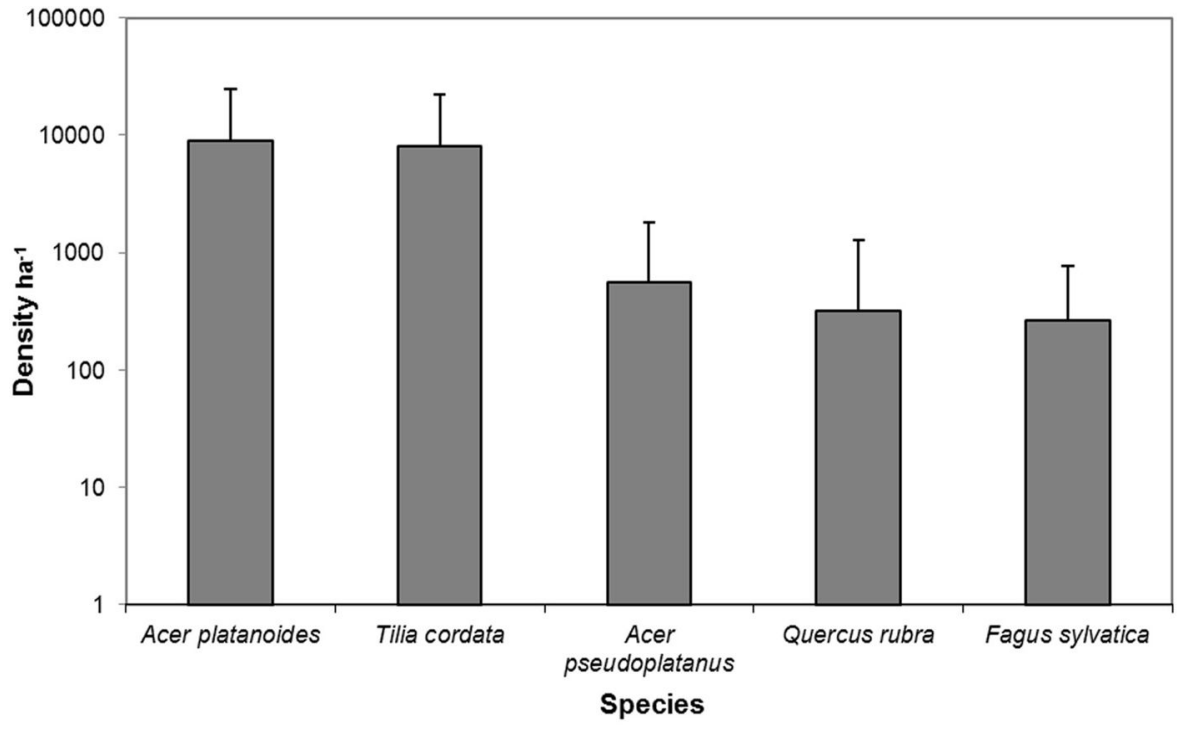

Fig. 3 - Density of saplings of different species in Scots pine stands with beech as secondary tree layer (mean \pm standard deviation). 


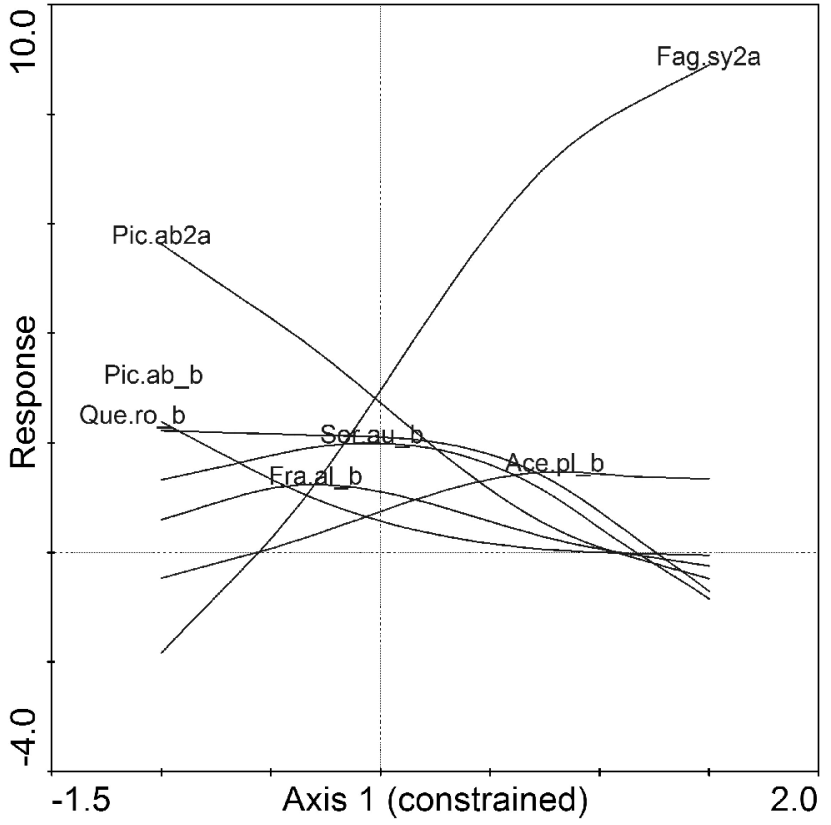

Fig. 4 - Generalized additive modeling (GAM) of shrubs and saplings. (Ace.pl._b): Acer platanoides; (Fra.al_b): Frangula alnus; (Fag.sy2a): Fagus sylvatica II tree layer; (Pic.ab2a): Picea abies II tree layer; (Pic.ab_b): Picea abies; (Que.ro_b): Quercus robur; (Sor.au b): Sorbus aucuparia.

ment of the second tree layer was higher in pine stands with planted beech (Tab. 3). Mean volume and the mean annual increment of the first tree layer dominated by pine did not differ significantly between the two types of stand (Tab. 3).

Results of the ANOVA carried out on light

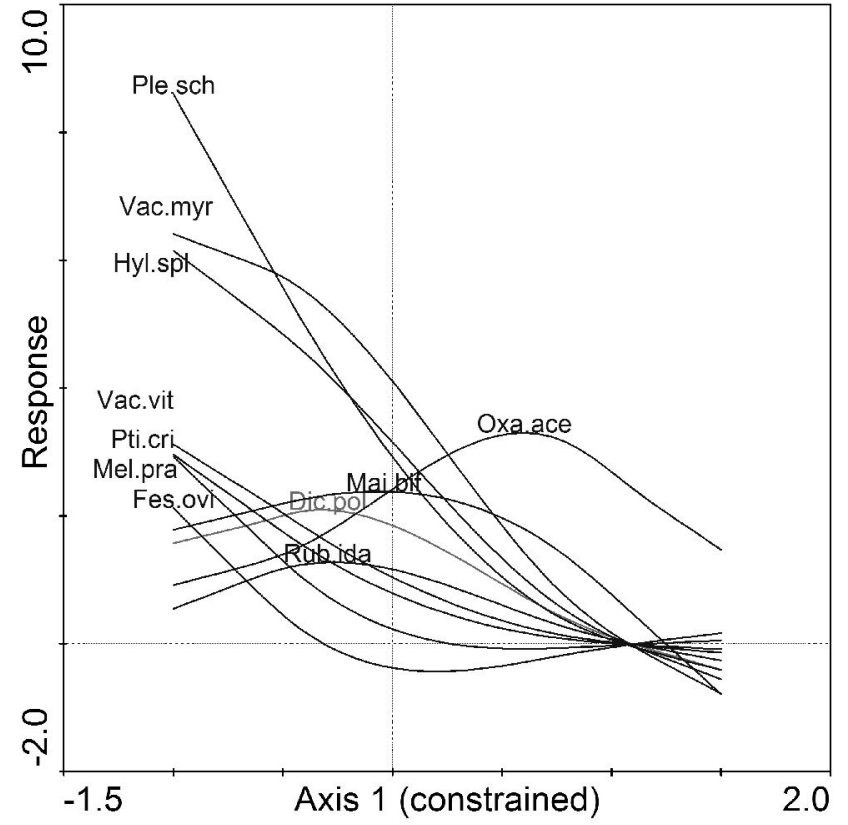

Fig. 5 - Generalized additive modeling (GAM) of herb and moss species (Dic.pol): Dicranum polysetum; (Fes.ovi): Festuca ovina; (Hyl.spl): Hylocomium splendens; (Mai.bif): Maianthemum bifolium; (Mel.pra): Melampyrum pratense; (Oxa.ace): Oxalis acetosella; (Ple.sch): Pleurozium schreberi; (Pti.cri): Ptilium cristacastrensis; (Rub.ida): Rubus idaeus; (Vac.myr): Vaccinium myrtillus.

indexes clearly showed that ISF, DFS and mean density was highest for Acer plataGSFs were higher in pine stands with spruce noides and Tilia cordata saplings. Quercus as the second tree layer, and that the LAI rubra, Fagus sylvatica and Acer pseudowas higher in pine stands with beech as the platanus were also present in the stand, but second tree layer (Tab. 4). Five tree sapling their density was tenfold lower than the Acer species in pine stands with European beech platanoides and Tilia cordata saplings (Fig. as the second tree layer were found. The 3). We found three tree sapling species

Tab. 5 - Frequency (\%) of recorded species in Scots pine stands with either beech (P. sylvestris - F. sylvatica) or spruce (P. sylvestris - P. abies) as second layers. (a1): I tree layer; (a2): II tree layer; (b): shrub layer; (c): herb layer; (d): moss layer.

\begin{tabular}{|c|c|c|c|c|c|c|c|}
\hline $\begin{array}{l}\text { Stand } \\
\text { layer }\end{array}$ & Species & $\begin{array}{c}\text { P. sylvestris - } \\
\text { F. sylvatica }\end{array}$ & $\begin{array}{l}\text { P. sylvestris - } \\
\text { P. abies }\end{array}$ & $\begin{array}{l}\text { Stand } \\
\text { layer }\end{array}$ & Species & $\begin{array}{c}\text { P. sylvestris - } \\
\text { F. sylvatica }\end{array}$ & $\begin{array}{l}\text { P. sylvestris - } \\
\text { P. abies }\end{array}$ \\
\hline al & Pinus sylvestris & 100 & 100 & $\mathrm{c}$ & Paris quadrifolia & 28 & 28 \\
\hline al & Picea abies & 63 & 71 & $\mathrm{c}$ & Fragaria vesca & 14 & 14 \\
\hline al & Fagus sylvatica & 28 & 0 & $\mathrm{c}$ & Vaccinium myrtillus & 0 & 100 \\
\hline a2 & Fagus sylvatica & 100 & 0 & $\mathrm{c}$ & Vaccinium vitis-idaea & 0 & 85 \\
\hline a2 & Picea abies & 0 & 100 & $\mathrm{c}$ & Melampyrum pratense & 0 & 71 \\
\hline a2 & Quercus robur & 14 & 28 & $\mathrm{c}$ & Rubus idaeus & 0 & 57 \\
\hline $\mathrm{b}$ & Fagus sylvatica & 100 & 14 & $\mathrm{c}$ & Luzula pilosa & 0 & 42 \\
\hline $\mathrm{b}$ & Acer platanoides & 71 & 0 & $\mathrm{c}$ & Calamagrostis arundinacea & 0 & 42 \\
\hline $\mathrm{b}$ & Acer pseudoplatanus & 28 & 0 & $\mathrm{c}$ & Trientalis europaea & 0 & 42 \\
\hline $\mathrm{b}$ & Quercus robur & 28 & 100 & $\mathrm{c}$ & Festuca ovina & 0 & 28 \\
\hline $\mathrm{b}$ & Sorbus aucuparia & 14 & 85 & $\mathrm{c}$ & Convallaria majalis & 0 & 14 \\
\hline $\mathrm{b}$ & Corylus avellana & 0 & 42 & $\mathrm{c}$ & Deschampsia flexuosa & 0 & 14 \\
\hline $\mathrm{b}$ & Frangula alnus & 0 & 57 & $\mathrm{c}$ & Melica nutans & 0 & 14 \\
\hline $\mathrm{b}$ & Lonicera xylosteum & 0 & 57 & $\mathrm{c}$ & Mycelis muralis & 0 & 14 \\
\hline $\mathrm{b}$ & Picea abies & 0 & 71 & $d$ & Dicranum polysetum & 0 & 71 \\
\hline $\mathrm{c}$ & Oxalis acetosella & 71 & 57 & d & Hylocomium splendens & 0 & 100 \\
\hline $\mathrm{c}$ & Dryopteris filix-mas & 71 & 28 & $\mathrm{~d}$ & Pleurozium schreberi & 0 & 100 \\
\hline $\mathrm{c}$ & Drypteris carthusiana & 71 & 57 & $\mathrm{~d}$ & Ptilium crista-castrensis & 0 & 71 \\
\hline $\mathrm{c}$ & Maianthemum bifolium & 28 & 100 & $\mathrm{~d}$ & Polytrichum formosum & 0 & 14 \\
\hline
\end{tabular}


(Picea abies, Quercus robur, Fagus sylvat$i c a$ ) in pine stands with spruce as the second tree layer.

GAM of species responses according to the CCA Axis I showed that only Acer platanoides in the shrub layer is associated with beech as the second tree layer (Fig. 4). Almost all species in the herb and moss layers were associated with pine stands without beech as the second tree layer, except for Oxalis acetosella (Fig. 5).

An examination of the understory herb and moss composition identified 14 species in Scots pine stands with beech as the second tree layer and 33 species in pine stands with spruce as the second tree layer. In stands with beech as the second tree layer, Acer platanoides, Acer peudoplatanus, Oxalis acetosella, Dryopteris filix-mas, and Dryopteris carthusiana were the most frequen species (Tab. 5). Moss species were totally absent in stands with beech as the second tree layer.

\section{Discussion}

Our data indicates that European beech planted under a Scots pine overstory reduces the understory vegetation cover and species diversity. Such changes could be caused by reduced light conditions, physical litter features or other related factors. It is generally thought that a conifer overstory allows for less understory diversity than does a deciduous tree overstory (Peterken 1996, Kint 2005). Barbier et al. (2008) stated that the assumption that a conifer overstory will always lead to lower species diversity may not be correct, and concluded that it is very difficult to generalize about the effects of tree species on understory diversity. Among deciduous species, beech stands have the lower vascular species diversity (Brunet et al 1996, Skov 1997), while species such as pine and larch appear to promote understory species diversity (Barbier et al. 2008). Mixed stands have been assumed to have a more species-rich flora than pure stands because they increase resource diversity (Hill 1992).

Coniferous species also promote bryophyte species richness (Ewald 2000). Previous studies have shown that, in European beech and Norway spruce stands, the relative abundance of spruce had a positive effect on bryophyte richness (Ewald 2000). Conversely, in another study on hornbeam in oak forests (Kwiatkowska 1994), an abundant second tree layer was found to have a negative effect on herbaceous species richness Our results showed that pine stands with beech as second layer had lower diversity of ground vegetation.

Light plays an important role in forest growth (Kirby 1988, Jennings et al. 1999, Barbier et al. 2008). Understory species vary in their optimal light requirements and canopy transmittance, depending on properties of the overstory tree species, which can be approximated from variables such as canopy closure or the leaf area index (LAI). Few studies have evaluated light conditions using different light-related ecological groups. Augusto et al. (2003) found that understory vegetation in Scots pine stands had higher Ellenberg's indicator values for light than understory vegetation in oak or spruce species' stands. Using ecological groups, Lücke \& Schmidt (1997) showed that understory vegetation was more light-demanding in spruce and mixed spruce beech stands than in pure beech stands.

Other factors, such as soil, water and nutrients, have significant effects on the relationship between overstory and understory diversity (Barkman 1992, Palik \& Engstrom 1999). The requirements for soil minerals and acidity/alkalinity differ among species (Ellenberg et al. 1992). It is generally accepted that conifers produce a more acidic topsoil than deciduous plants, but this generalization is sometimes incorrect. Among deciduous species, beech produces more acidic topsoils than other hardwoods (Neirynck et al. 2000, Hagen-Thorn et al. 2004). In this study, soil $\mathrm{pH}$ did not differ significantly between a pine forest with beech as the second tree layer and a pine forest with spruce as the second tree layer. Aubert et al. (2004) also found a more acidic topsoil under pure beech than under a mixture of beech and hornbeam, and the acidity correlated with the higher number of acidophilous species under the pure beech stands.

Bryophytes and herbaceous species often do not have the same responses to soil modifications. Some authors consider acidic soil conditions to be favorable to bryophytes (Harris \& Harris 1997), especially to their ability to cover the forest floor (Ewald 2000).

Forest floor litter also has physical effects on understory vegetation (Facelli \& Pickett 1991, Ellsworth et al. 2004). Generally, a thicker litter layer is found under conifers than under deciduous trees. Bryophyte species are more sensitive to the physical effects of litter than vascular species (Hill 1979). Ewald (2000) suggested that the higher abundance of mosses under spruce than under deciduous trees was a consequence of their ability to creep along the abundant litter without making contact with the mineral soil layer; however, the slow growth rate of bryophytes under the relatively large leaves of deciduous trees makes them sensitive to the degree of cover.

\section{Conclusions}

The main results of the investigation carried out may be summarized as follows:

1. Species diversity in pine stands with planted beech as the second tree layer was lower than in pine stands with spruce as the second layer. The cover of shrub, herbs and mosses layers was significantly lower, the soil humus (A) layer was thicker, and the organic $(\mathrm{O})$ soil layer was thinner in pine stands with beech as the second tree layer.

2. Stand parameters such as mean volume and mean annual increment of the second tree layer were significantly higher in pine stands with planted beech second tree layers than in pine stand with a spruce second tree layer. Mean volume and mean annual increment of first tree layer (dominated by Scots pine) did not differ significantly between stands with planted beech and natural spruce understory.

3. Beech under a pine overstory had negative effects on understory species richness and abundance. This was most likely due to differences in light transmittance and in the physical properties of the litter under beech trees.

The above results should be taken into consideration by forest managers, especially when managing forests in protected areas.

\section{Acknowledgments}

This research was funded by a grant (no. LEK-19/2010) from the Research Council of Lithuania. We are thankful to the two anonymous referees for their valuable comments.

\section{References}

Aubert M, Bureau F, Alard D, Bardat J (2004). Effect of tree mixture on the humic epipedon and vegetation diversity in managed beech forests (Normandy, France). Canadian Journal of Forest Research 34: 233-248. - doi: 10.1139/x03-205

Augustaitis A, Jasineviciene D, Girgždiene R, Kliučius A, Marozas V (2012). Sensitivity of beech trees to global environmental changes at most North-Eastern latitude of their occurrence in Europe. The Scientific World Journal, Article ID 743926, pp. 12. - doi: 10.1100/2012/743926

Augusto L, Dupouey JL, Ranger J (2003). Effects of tree species on understory vegetation and environmental conditions in temperate forests. Annals of Forest Science 60: 823-831. - doi: 10.1051/forest:2003077

Barbier S, Gosselin F, Balandier P (2008). Influence of tree species on understory vegetation diversity and mechanisms involved - a critical review for temperate and boreal forests. Forest Ecology and Management 254: 1-15. - doi: 10.1016/j.foreco.2007.09.038

Barkman JJ (1992). Canopies and microclimate of tree species mixtures. In: "The ecology of mixedspecies stands of trees" (Cannell MGR, Malcolm DC, Robertson PA eds). Blackwell Scientific Publications, Oxford, UK, pp. 181-188.

Björkman L, Bradshaw R (1996). The immigration of Fagus sylvatica L. and Picea abies (L.) Karst. into a natural forest stand in southern Sweden during the last 2000 years. Journal of Biogeography 23: 235-244. - doi: 10.1046/j. 
1365-2699.1996.00972.x

Bolte A, Hilbrig L, Grundmann B, Kampf F, Brunet J, Roloff A (2010). Climate change impacts on stand structure and competitive interactions in a southern Swedish spruce-beech forest European Journal of Forest Research 129: 261276.

Braun-Blanquet J (1983). Plant sociology: the study of plant communities (Fuller GD, Conard HS eds). Koeltz Scientific Books, Konigstein, Germany.

Brunet J, Falkengren-Grerup U, Tyler G (1996) Herb layer vegetation of south Swedish beech and oak forests-effects of management and soil acidity during one decade. Forest Ecology and Management 88: 259-272. - doi: 10.1016/S03781127(96)03845-5

Bukantis A (1994). Lietuvos klimatas [Climate of Lithuania]. Vilnius University Press, Vilnius, Lithuania. [In Lithuanian]

Deal RL (2007). Management strategies to increase stand structural diversity and enhance biodiversity in coastal rainforest of Alaska. Biological Conservation 137: 520-532. - doi: 10.1016/j.biocon.2007.03.014

Ellenberg H, Weber HE, Düll R, Wirth V, Werner W, Paulissen D (1992). Zeigerwerte von Pflanzen in Mitteleuropa. Scripta Geobotanica 18: 1248 .

Ellsworth J, Harrington R, Fownes J (2004). Seedling emergence, growth, and allocation of oriental bittersweet: effects of seed input, seed bank, and forest floor litter. Forest Ecology and Management 190: 255-264. - doi: 10.1016/j.foreco. 2003.10.015

Estevan H, Lloret F, Vayreda J, Terradas J (2007). Determinants of woody species richness in Scots pine and beech forests: climate, forest match size and forest structure. Acta Oecologica 31: 325 331. - doi: 10.1016/j.actao.2007.01.003

Ewald J (2000). The influence of coniferous canopies on understorey vegetation and soils in mountain forests of the northern Calcareous Alps. Applied Vegetation Science 3:123-134. doi: $10.2307 / 1478926$

Facelli JM, Pickett STA (1991). Plant litter: its dynamics and effects on plant community structure. Botanical Review 57:1-32. - doi: 10.1007/ BF02858763

Giesecke T, Hickler T, Kunkel T, Sykes MT, Bradshaw RHW (2007). Towards an understanding of the Holocene distribution of Fagus sylvatica L. Journal of Biogeography 34: 118131. - doi: 10.1111/j.1365-2699.2006.01580.x Gilliam FS (2007). The ecological significance of the herbaceous layer in temperate forest ecosystems. BioScience 57: 845-858. - doi: 10.1641/ B571007

Gracia M, Montané F, Piqué J, Retana J (2007). Overstory structure and topographic gradients determining diversity and abundance of understory shrub species in temperate forests in central Pyrenees (NE Spain). Forest Ecology and Management 242: 391-397. - doi: 10.1016/j.foreco.
2007.01.056

Hagen-Thorn A, Callesen I, Armolaitis K, Nihlgard B (2004). The impact of six European tree species on the chemistry of mineral topsoil in forest plantations on former agricultural land. Forest Ecology and Management 195: 373-384. doi: 10.1016/j.foreco.2004.02.036

Harris E, Harris J (1997). Wildlife conservation in managed woodlands and forests. John Wiley, Chichester, UK

Hill MO (1979). The development of a flora in even-aged plantations. In: "The ecology of evenaged forest plantations" (Ford ED, Malcolm DC, Atterson J eds). Institute of Terrestrial Ecology, Cambridge, UK, pp. 175-192.

Hill MO (1992). Mixtures as habitats for plants. In: "The ecology of mixed-species stands of trees" (Cannell MGR, Malcolm DC, Robertson PA eds). Blackwell Scientific Publications, Oxford, UK, pp. 301-302.

Huntley B, Bartlein PJ, Prentice IC (1989). Climatic control of the distribution and abundance of beech (Fagus L.) in Europe and North America. Journal of Biogeography 16: 551-560. - doi: $10.2307 / 2845210$

IPCC (2007). Climate Change 2007: The physical science basis. Contribution of working group I to the fourth assessment report of the intergovernmental panel on climate change. Cambridge University Press, Cambridge, UK.

Jankevičiene R (1998). Dictionary of plant names. Institute of Botany Publisher, Vilnius, Lithuania. Jennings SB, Brown ND, Sheil D (1999). Assessing forest canopies and understorey illumination: canopy closure, canopy cover and other measures. Forestry 72: 59-73. - doi: 10.1093/ forestry/72.1.59

Kint V (2005). Structural development in ageing temperate Scots pine stands. Forest Ecology and Management 214: 237-250. - doi: 10.1016/j.foreco.2005.04.014

Kint V, Geudens G, Mohren GMJ, Lust N (2006). Sylvicultural interpretation of natural vegetation dynamics in ageing Scots pine stands for their conversion into mixed broadleaved stands. Forest Ecology and Management 223: 363-370. doi: 10.1016/j.foreco.2005.11.018

Kirby KJ (1988). Changes in the ground flora under plantations on ancient woodland sites. Forestry 61: 317-338. - doi: 10.1093/forestry/61. 4.317

Kwiatkowska AJ (1994). Changes in the species richness, spatial pattern and species frequency associated with the decline of oak forest. Vegetatio 112: 171-180. - doi: 10.1007/BF00044691

Lepš J, Šmilauer P (2003). Multivariate analysis of ecological data using CANOCO. Cambridge University Press, Cambridge, UK. pp. 267.

Leuschner C, Meier IC, Hertel D (2006). On the niche breadth of Fagus sylvatica: soil nutrient status in 50 Central European beech stands on a broad range of bedrock types. Annals of Forest Science 63: 335-368. - doi: 10.1051/forest: 2006016
Lücke K, Schmidt W (1997). Vegetation und Standortsverhältnisse in Buchen-Fichten-Mischbeständen des Sollings. Forstarchiv 68: 135 143. [in German]

Marcos E, Calvo L, Marcos JM, Taboada A, Tárrega $\mathrm{R}$ (2010). Tree effects on the chemical topsoil features of oak, beech and pine forests. European Journal of Forest Research 129: 25-30. - doi: 10.1007/s10342-008-0248-0

Marcos JA, Marcos E, Taboada A, Tarrega R (2007). Comparison of community structure and soil characteristics in different aged Pinus sylvestris plantations and a natural pine forest. Forest Ecology and Management 247: 35-42. doi: 10.1016/j.foreco.2007.04.022

Neirynck J, Mirtcheva S, Sioen G, Lust N (2000). Impact of Tilia platyphyllos Scop., Fraxinus excelsior L., Acer pseudoplatanus L., Quercus robur L. and Fagus sylvatica L. on earthworm biomass and physicochemical properties of a loamy topsoil. Forest Ecology and Management 133: 275-286. - doi: 10.1016/S0378-1127(99) 00240-6

North M, Oakley B, Fiegener R, Gray A, Barbour $\mathrm{M}$ (2005). Influence of light and soil moisture on Sierrran mixed-conifer understory communities. Plant Ecology 177:13-24. - doi: 10.1007/s11258005-2270-3

Palik B, Engstrom RT (1999). Species composition. In: "Maintaining biodiversity in forest ecosystems" (Hunter MJ ed). Cambridge University Press, Cambridge, UK, pp. 65-94.

Peterken GF (1996). Natural woodland ecology and conservation in northern temperate regions. Cambridge University Press, Cambridge, UK, pp. 518.

Skov F (1997). Stand and neighbourhood parameters as determinants of plant species richness in a managed forest. Journal of Vegetation Science 8: 573-578. - doi: 10.2307/3237209

Straigyte L, Marozas V, Zalkauskas R (2012). Morphological traits of Red oak (Quercus rubra L.) and ground vegetation in stands different sites and regions in Lithuania. Baltic Forestry 18 (1): 91-99.

Riepsas E, Straigyte L (2008). Invasiveness and ecological effects of Red Oak (Quercus rubra L.) in Lithuanian forests. Baltic Forestry 14: 122-130.

Repšys J (1994). Miško taksacija [Forest measurement]. Mokslas, Vilnius, Lithuania. [in Lithuanian]

ter Braak CJF, Šmilauer P (1998). CANOCO Release 4. Reference manual and user's guide to Canoco for Windows: Software for Canonical Community ordination. Microcomputer Power, Ithaca, New York, USA.

von Wuehlisch G (2008). EUFORGEN technical guidelines for genetic conservation and use for European beech (Fagus sylvatica). Bioversity International, Rome, Italy.

Webb N (1999). HemiView user manual - version 2.1. Delta_T Devices Ltd., Cambridge, UK. 